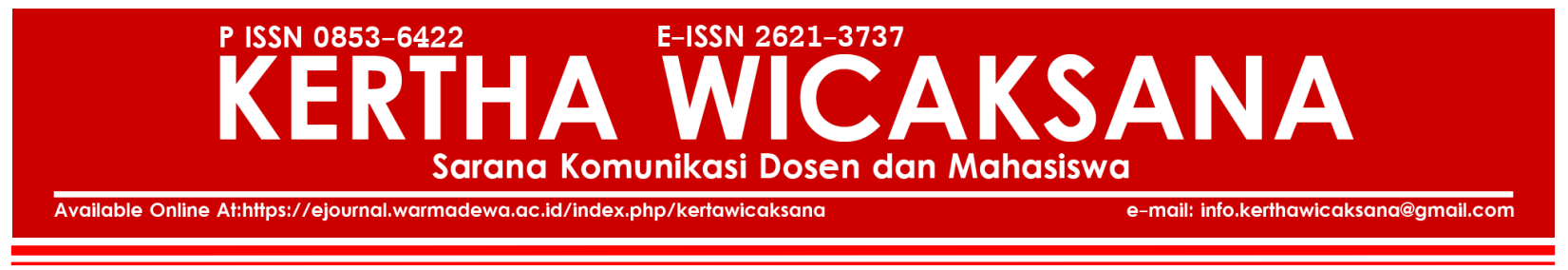

\title{
Pemenuhan Hak Pilih Bagi Disabilitas dalam Pemilu oleh KPU di Sumatera Barat
}

\author{
Nurbeti dan Helmi Chandra SY \\ Fakultas Hukum Universitas Bung Hatta, Sumatera Barat-Indonesia \\ nurbeti.purwa@gmail.com dan helmichandrasy30@gmail.com
}

Published: 25/07/2021

How To Cite:

Nurbeti., \& SY, H. C. (2021). Pemenuhan Hak Pilih Bagi Disabilitas dalam Pemilu oleh KPU di Sumatera Barat. KERTHA WICAKSANA: Sarana Komunikasi Dosen dan Mahasiswa. 15(2). Pp 130-137. https:// doi.org/10.22225/kw.15.2.2021.130-137

\begin{abstract}
Abstrak
Penyandang disabilitas memiliki hak, kedudukan dan kewajiban yang sama dengan warga negara lainnya. Berdasarkan data potensial pemilih pemilu (DP4) bulan desember tahun 2018 bahwa penyandang disabilitas di Sumatera Barat sebanyak 9.172 jiwa. Besarnya jumlah disailitas dapat memberikan peluang akan kecurangan dalam pemilihan umum. Tujuan penelitian ini untuk mengetahui pemenuhan hak pilih bagi disabilitas khususnya di provinsi Sumatera Barat. Pendekatan dalam penelitian ini adalah yuridis sosiologis yaitu suatu studi yang meninjau hukum sebagai fakta sosial. Hasil penelitian menunjukan bahwa pemenuhan hak pilih bagi penyandang disabilitas dalam pemilu serentak oleh Komisi Pemilihan Umum (KPU) di Sumatera Barat dilakukan dengan melakukan pendataan, sosialisasi dan memberikan akses. Kendala dalam pemenuhan hak pilih yaitu paradigma keluarga, paradigma petugas dan minimnya data disabilitas.
\end{abstract}

Kata Kunci: Pemenuhan; Hak Pilih; Disabilitas; Pemilu

\section{Abstract}

Persons with disabilities have the same rights, positions and obligations as other citizens. Based on data on potential electoral voters (DP4) in December 2018, there are 9,172 people with disabilities in West Sumatra. The large number of disailments can provide an opportunity for fraud in general elections. The purpose of this study is to determine the fulfillment of suffrage rights for disabilities, especially in West Sumatra province. The approach in this research is sociological juridical, namely a study that reviews law as a social fact. The results showed that the fulfillment of voting rights for persons with disabilities in simultaneous elections by the General Election Commission (KPU) in West Sumatra was carried out by collecting data, socializing and providing access. Obstacles in fulfilling the right to vote are the family paradigm, the paradigm of officers and the lack of data on disabilities.

\section{Keywords: Fulfillment; Voting Rights; Disabilities; Election}

\section{PENDAhULUAN}

Disabilitas mempunyai hak, kedudukan dan kewajiban yang setara dengan semua warga negara. Hal tersebut tercantum dalam UndangUndang Dasar 1945 Pasal 28 huruf D ayat (1) yang menjelaskan bahwa setiap orang berhak atas pengakuan jaminan perlindungan dan kepastian hukum yang adil serta perlakuan yang sama dihadapan hukum. Salah satunya termasuk jaminan untuk menggunakan hak politik sebagai pemilih dalam penyelenggaraan pemilu. Dalam Pasal 13 Undang-Undang Nomor 8 Tahun 2016 tentang Penyandang Disabilitas menjelaskan bahwa hak-hak politik bagi disabilitas meliputi hak dipilih dan memilih dalam kegiatan politik, serta diperbolehkan menyalurkan aspirasi politik tersebut baik tertulis atau lisan (Anam, 2011).

Hak pilih sesungguhnya menjadi bagian hak asasi manusia yang melekat pada manusia yang perlindungannya juga dijamin oleh negara. Disebabkan oleh karakteristik yang hampir sama dengan hak lainnya maka hak pilih sebagai hak dasar harus dipenuhi tanpa melihat perbedaan atas suku, bangsa, ataupun jenis kelamin (Rahmanto, 


\section{9).}

Senada dengan itu, dalam Pasal 5 UndangUndang Nomor 7 Tahun 2017 tentang pemilu yang menjelaskan bahwa disabilitas yang memenuhi syarat memiliki kesempatan yang sama sebagai pemilih, sebagai calon anggota DPR, DPD, DPRD, Calon Presiden dan Wakil Presiden serta sebagai penyelenggara Pemilu. Hal itu juga dipertegas oleh putusan Mahkamah Konstitusi Nomor 135/PUU-XIII/2015, MK berpendapat bahwa disabilitas gangguan jiwa atau gangguan ingatan yang memiliki sisi kecepatan pemulihan maupun tetap berhak mendapatkan hak pilih dalam pemilu.

Selanjutnya, berdasarkan Surat Edaran KPU Nomor 1401/PL.02.1-SD/01/KPU/XI/2018, KPU dalam pemilu 2019 melakukan pendaftaran terhadap pemilih disabilitas agar dapat memperoleh hak pilihnya dalam pemilu. Indonesia sebagai negara demokrasi pasti menjunjung tinggi hak-hak masyarakat termasuk dalam Pemilu. Hal itu harus dilaksanakan dalam suasana terjaminnya kebebasan politik termasuk bagi penyandang disabilitas (Huda, 2011).

KPU sebagai lembaga peyelenggara pemilu harus melakukan tugas dan fungsinya sebagai penyelenggara teknis dan administratif pemilu. KPU juga wajib melakukan pemenuhan hak politik dalam Pemilu yang dilaksanakan di Sumatera Barat. Berdasarkan Data Potensial Pemilih Pemilu (DP4) bulan Desember tahun 2018 bahwa Penyandang Disabilitas di Sumatera Barat sebanyak 9.172 jiwa. Artinya jika dikonversikan dalam bentuk prosentase, penyandang disabilitas di Kota Padang mencapai $0,037 \%$ dari total DP4.

Banyaknya pemilih disabilitas di Sumatera Barat sehingga pemenuhan hak pilih bagi pemilih disabilitas harus dilakukan dengan baik dan serius. Jangan sampai dengan adanya pemberian hak pilih memberikan peluang akan kecurangan dalam pemilu. Penelitian ini bertujuan untuk mengkaji proses pemenuhan hak pilih bagi disabilitas sehingga menjamin terciptanya pemilu yang inklusif di Sumatera Barat.

\section{METODE}

Pendekatan yang digunakan dalam penelitian ini adalah pendekatan yuridis sosiologis, yaitu pemaparan dan pengkajian hubungan aspek hukum dengan aspek non hukum dalam bekerjanya hukum di dalam kenyataan. Pendekatan yuridis sosiologis adalah untuk menjawab pertanyaan mengenai tinjauan pemenuhan hak pilih bagi disabilitas dalam pemilu serentak oleh KPU di Sumatera Barat.

\section{HASIL DAN PEMBAHASAN}

\section{Proses Pemenuhan Hak Pilih Bagi Disabilitas dalam Pemilu Serentak oleh KPU di Sumatera Barat}

Pemilu sejatinya bertujuan untuk melaksanakan hak asasi politik masyarakat. Pelaksanaan hak ini diwujudkan dengan memberikan kesempatan yang sebesar-besarnya kepada masyarakat untuk ikut dan berperan di dalam pemerintahan. Hal ini juga berlaku bagi penyandang disabilitas. Keikutsertaan disabilitas dalam pemilu menjadi bukti bahwa pemilu merupakan gambaran kemanusiaan, karena banyak pandangan serta anggapan kepada disabilitas sebagai orang cacat, lemah dan tidak penting sehingga menafikan kemampuan serta integritas disabilitas untuk terlibat dalam pemilu (SY, 2019).

Menurut Pusat Pemilihan Umum Akses (PPUA) pada pemilu 2019 setidaknya ada 55 orang caleg disabilitas di seluruh Indonesia mulai dari caleg DPRD kabupaten/kota hingga caleg DPR RI namun yang terdata lengkap baru 35 orang caleg. Hal ini memperlihatkan bahwa kurangnya perhatian terhadap caleg disabilitas padahal UU Nomor 7 Tahun 2017 tentang Pemilu telah mengatur kesamaan hak dan kesempatan bagi setiap warga negara untuk berpartisipasi dalam pemilu termasuk disabilitas (SY, 2019).

Besarnya antusiasme warga negara tanpa adanya diskriminasi untuk menggunakan hak pilihnya di Tempat Pemungutan Suara (TPS) menjadi salah satu cirri pemilu demokratis. Semakin tingginya partisipasi masyarakat maka akan memiliki konsekuensi tinggi terkait kualitas demokrasi. Untuk menjamin hal itu, maka dalam hal pemenuhan hak pilih bagi penyandang disabilitas KPU provinsi Sumatera Barat melakukan kegiatan sebagai berikut :

\section{Melakukan Pendataan}

Agar hak pilih bagi penyandang disabilitas dapat terpenuhi, maka diperlukan pendataan khusus karena penyandang disabilitas membutuhkan perhatian dan kebutuhan khusus. Hal ini mengingat bahwa setiap jenis kedisabilitasan membutuhkan pelayanan dan fasilitas yang berbeda. Pada tahap pendaftaran pemilih penyandang disabilitas ini, Petugas Pemutakhiran Data Pemilih (PPDP) melakukan 
pendataan untuk pendaftaran pemilih penyandang disabilitas. Pada tahap ini PPDP melakukan pendaftaran penyandang disabilitas sesuai dengan disabilitas yang diderita oleh peserta pemilih yang terdaftar.

Pendataan pemilih penyandang disabilitas merupakan upaya untuk memastikan setiap penyandang disabilitas yang telah memenuhi syarat sebagai pemilih dalam Pemilu terdaftar dalam Daftar Pemilih Tetap sehingga masyarakat penyandang disabilitas selanjutnya dapat menggunakan hak pilihnya. Sedangkan adanya identifikasi pemilih penyandang disabilitas merupakan upaya lanjutan yang mana dari identifikasi tersebut nantinya dapat melahirkan konsep pelayanan atau pemfasilitasan di setiap TPS bagi penyandang disabilitas dalam rangka mewujudkan Pemilu yang ramah disabilitas (Halalia, 2017).

Klasifikasi Disabilitas berdasarkan UU No.8 Tahun 2016 keragamannya ada 4 (empat) yaitu sensorik (indrawian), gerak dan fisik (cacat tubuh), intelektual (keterbelakangan mental) dan mental (ingatan dan psikososial). Sedangkan dilapangan keragaman diklasifikasikan ke dalam ciri fisik (hambatan penglihatan, tunanetra, gangguan pendengaran dan bicara, tunarungu, tuli, cacat tubuh/fisik, keterbelakangan mental, gangguan konsentrasi, autis. Namun tetap kembali merujuk pada UU, defenisi di kementrian sosial, kementrian kesehatan daan PKPU.

Pada pelaksanaan Pemilu, salah satu masyarakat yang kurang mendapatkan perhatian dan rentan mengalami diskriminasi adalah kaum disabilitas (diffable). KPU provinsi Sumatera Barat melakukan pendataan pada penderita disabilitas di Sumatera Barat pada setiap kategori penyandang disabilitas. Dalam pendataan disabilitas dapat dilihat pada tabel berikut ini.

Tabel 1

Data Pemilih Penyandang Disabilitas di Sumatera Barat 2019 2019

Sumber: KPU Provinsi Sumatera Barat, Tahun

\begin{tabular}{ccc}
\hline No & Klasifikasi & Jumlah \\
\hline 1 & Tuna Daksa & 2.207 \\
2 & Tuna Netra & 1.180 \\
3 & Tuna Rungu/Wicara & 1.889 \\
4 & Tuna Grahita & 2.024 \\
5 & Disabilitas Lainnya & 2.078 \\
& Total & $\mathbf{9 . 3 7 8}$ \\
\hline
\end{tabular}

Berdasarkan tabel di atas dapat dilihat bahwa penyandang disabilitas di provinsi Sumatera Barat masih banyak dengan jumlah total 9378 orang. Kategori penyandang disabilitas tertinggi adalah tuna daksa (2207) dan kategori penyandang disabilitas terendah adalah tuna netra (1180). Namun meskipun demikian secara jumlah penyandang disabilitas di provinsi Sumatera Barat memenuhi 3 (tiga) klasifikasi yaitu sensorik (Indrawian), gerak dan fisik (Cacat tubuh), intelektual (Keterbelakangan mental ).

Kondisi ini diatasi oleh penyelenggara melalui proses pencocokan dan penelitian. KPU melakukan pendataan pemilih dalam pemenuhan hak pilih bagi disabilitas dalam pemilu. Tujuannya untuk mendapatkan data pemilih disabilitas yang memenuhi syarat untuk melakukan pemilihan dengan mendatanya kedalam daftar pemilih. Pada kegiatan ini petugas pemutakhiran pemilih mencantumkan kode jenis disabilitas dalam kolom keterangan daftar pemilih (angka 1 untuk tuna daksa, angka 2 untuk tuna netra, angka 3 untuk tuna rungu/wicara, angka 4 untuk tuna grahita, angka 5 untuk tuna lainnya). Hal ini agar pemilih penyandang disabilitas ini dapat terkelompok sehingga memudahkan dalam pemenuhan hak pilih disabilitas pada hari pencoblosan.

Sementara itu khusus untuk penyandang disabilitas di ibu kota provinsi Sumatera Barat yakni kota Padang memiliki jumlah penyandang disabilitas paling besar dan menyumbang kategori disabilitas terbanyak. Jumlah pemilih disabilitas di kota Padang dapat dilihat pada tabel berikut:

Tabel 2

Jumlah Pemilih Disabilitas di Kota Padang 2019

\begin{tabular}{lcccccc}
\hline 1 & $\begin{array}{c}\text { Padang } \\
\text { Selatan }\end{array}$ & 38.300 & 17 & 5 & 17 & 10 \\
2 & $\begin{array}{c}\text { Padang } \\
\text { Timur }\end{array}$ & 51.701 & 33 & 14 & 30 & 25 \\
3 & $\begin{array}{c}\text { Padang } \\
\text { Barat }\end{array}$ & 29.250 & 11 & 9 & 15 & 9 \\
4 & $\begin{array}{c}\text { Padang } \\
\text { Utara }\end{array}$ & 44.353 & 12 & 9 & 29 & 21 \\
5 & Bungus & 17.832 & 7 & 3 & 13 & 6 \\
\hline
\end{tabular}




\begin{tabular}{ccccccc}
\hline & & & & & & \\
6 & $\begin{array}{c}\text { Lubuk } \\
\text { Begalung }\end{array}$ & 75.542 & 31 & 21 & 34 & 24 \\
7 & $\begin{array}{c}\text { Lubuk } \\
\text { Kilangan }\end{array}$ & 36.095 & 18 & 17 & 12 & 12 \\
8 & Pauh & 41.371 & 9 & 10 & 11 & 13 \\
9 & Kuranji & 94.626 & 34 & 15 & 26 & 21 \\
10 & Nanggalo & 37.109 & 28 & 15 & 24 & 21 \\
11 & Koto Tangah & 126.100 & 60 & 24 & 33 & 41 \\
& TOTAL & $\mathbf{5 9 2 . 2 7 9}$ & $\mathbf{2 6 0}$ & $\mathbf{1 4 2}$ & $\mathbf{2 4 4}$ & $\mathbf{2 0 3}$ \\
\hline
\end{tabular}

Sumber: KPU Kota Padang, Tahun 2019

Dari tabel diatas dapat terlihat bahwa jumlah disabilitas terbanyak ada di kecamatan Padang Utara (212) dan kecamatan dengan penyandang disabilitas paling sedikit berada di kecamatan Bungus (34). Padahal kecamatan dengan jumlah pemilih terbanyak ada di kecamatan Koto Tangah dengan 126.100 orang pemilih.

\section{Sosialisasi}

KPU dalam melaksanakan pemenuhan hak pilih bagi penyandang disabilitas melakukan sosialisasi baik kepada petugas pelaksana pemilu, pengawas, rewalan dan sampai pada penyandang disabilitas itu sendiri. Selain itu, KPU juga melakukan sosialisasi kepada organisasi penyandang disabilitas (OPD) untuk membuka akses informasi kepada penyandang disabilitas yang aktif dalam komunitas. Namun di sisi lain, populasi penyandang disabilitas diluar komunitas masih jauh lebih banyak dan tidak tersentuh akses informasi kepemiluan. Penyebabnya, karena proses pendidikan terhadap pemilih kepada penyandang disabilitas masih dianggap kurang sehingga tidak mencapai golongan masyarakat yang berada diluar komunitas.

Salah satu OPD yang diundang KPU adalah Persatuan Penyandang Disabilitas Indonesia (PPDI) yang kini sudah berganti nama menjadi Perkumpulan Penyandang Disabilitas Indonesia yang merupakan organisasi payung dan beranggotakan beragam organisasi disabilitas di Indonesia yang didirikan pada tahun 1987. PPDI memiliki visi untuk menciptakan partisipasi penuh dan persamaan peluang penyandang disabilitas dalam semua aspek kehidupan. Lembaga ini berfungsi sebagai lembaga koordinasi dan advokasi bagi para anggotanya, sedangkan bagi pemerintah PPDI merupakan mitra dalam pembuatan berbagai kebijakan dan kegiatan-kegiatan yang berkaitan dengan penyandang disabilitas.

Sebagai lembaga perkumpulan disabilitas, PPDI mempunyai jaringan kerja hampir disemua provinsi di Indonesia dan menjadi bagian dari anggota Disabled People Internasional. Mulai tahun 2005, PPDI bersama dengan organisasi jaringannya selalu terlibat dalam pemberian konsep naskah akademis bagi proses ratifikasi CRPD sehingga menjadi UU No. 8 Tahun 2016 Tentang Penyandang Disabilitas. Dalam kerjakerjanya PPDI memiliki misi yaitu:

Melakukan koordinasi dan konsultasi tentang semua hal yang berkaitan dengan disabilitas.

Melakukan advokasi terhadap hak dan peningkatan kesejahteraan disabilitas.

Menyeimbangkan kewajiban dan hak penyandang disabilitas sebagai warga negara Indonesia.

Mengupayakan keterpaduan langkah, potensi disabilitas dalam peningkatan bagi kualitas, efektifitas, efesiensi dan relevansi atas kemitraan yang saling menguntungkan dan bermartabat.

Memberdayakan penyandang disabilitas agar turut berperan serta sebagai pelaku pembangunan yang mandiri, produktif dan berintegrasi.

Mengadakan kampanye kepedulian dan kesadaran bagi masyarakat sebagai media sosialisasi dan informasi tentang disabilitas kepada berbagai kalangan.

Misi PPDI tersebut memiliki tujuan untuk dapat memperjuangkan pemberian hak bagi penyandang disabilitas agar bisa memperoleh persamaan peluang dalam semua bidang kegiatan dalam kehidupan serta dapat berpartisipasi penuh sebagai warga negara dalam pemerintahan dan pembagunan.

Namun selama ini pihak penyelenggara masih dalam tataran memberikan sosialisasi kepada para penyandang disabilitas dalam hal untuk memilih dan tata cara pemilihan. Hambatan yang muncul dari pihak Komisi Pemilihan Umum adalah kesulitan menyampaikan materi sosialisasi kepada penyandang disabilitas (Maulana et al., 2020). Demikianlah bentuk sosialisasi yang dilakukan KPU provinsi Sumatera Barat di Kota Padang dapat dilihat pada tabel berikut ini: 
Tabel 3

Bentuk Sosialisasi Pemilu Kepada Disabilitas

\begin{tabular}{|c|c|c|c|c|}
\hline No & Bentuk & Pelaksana & Waktu & Kerjasama \\
\hline 1 & Workshop & $\begin{array}{l}\text { Komisioner } \\
\text { KPU }\end{array}$ & $\begin{array}{l}\text { November } \\
2018\end{array}$ & Dokter \\
\hline 2 & Pembekalan & $\begin{array}{l}\text { Komisioner } \\
\mathrm{Kpu}\end{array}$ & $\begin{array}{l}\text { Desember } \\
2018\end{array}$ & $\begin{array}{l}\text { Psikiater } \\
\text { Guru } \\
\text {-Disabilitas }\end{array}$ \\
\hline 3 & $\begin{array}{l}\text { Sosialisasi } \\
\text { dan } \\
\text { Simulasi }\end{array}$ & Relawan & $\begin{array}{l}\text { Desember } \\
2018 \text {, Maret } \\
2019\end{array}$ & $\begin{array}{l}\text { Rumah } \\
\text { Sakit }\end{array}$ \\
\hline
\end{tabular}

Sumber: KPU Provinsi Sumatera Barat Tahun 2019

Berdasarkan tabel di atas terlihat bahwa KPU provinsi Sumatera Barat melakukan 3 (tiga) program sosialisasi dalam bentuk workshop, pembekalan dan simulasi. Program sosialisasi pemilu ini tidak hanya dilakukan oleh KPU saja sebagai penyelenggara pemilu namun juga bekerja sama dengan relawan, dokter psikiater dan guru-guru disabilitas.

\section{Memberikan Akses}

Penyandang disabilitas mendapatkan berbagai hambatan yang membatasi akses mereka dalam keikutsertaannya dalam pemilihan umum, antara lain: keterbatasan akses informasi, keterbatasan pengetahuan, ketidaktersediaan sejumlah instrument teknis, dan persepsi masyarakat yang memandang rendah martabat kelompok penyandang disabilitas sebagai pemilih (Waisnawa \& Dewi, 2019).

Untuk tersedianya sarana dan prasarana yang mudah diakses oleh pemilih penyandang disabilitas dan terciptanya prinsip luber dan jurdil dalam penyelenggaraan pemilu, maka KPU merumuskan beberapa regulasi terkait. Peraturanperaturan yang diatur dalam undang-undang meliputi:

Selain Perlengkapan pemungutan suara, KPU juga mendistribusikan alat bantu tuna netra demi menjaga keamanan, kerahasiaan, dan kelancaran pelaksanaan pemungutan suara dan penghitungan suara.

Dalam memberikan suaranya, pemilih penyandang disabilitas bisa dipandu oleh orang lain yang telah ditunjuk oleh pemilih disabilitas dan orang tersebut wajib merahasiakan pilihannya.

Dalam pemilu legislatif, asas kerahasiaan tersebut juga berlaku bagi pemilih penyandang disabilitas yang bermukim di luar negeri.

Saat pemilu presiden dan wapres, bagi pemilih penyandang disabilitas yang berdomisili di luar negeri dan tidak bisa menyalurkan suaranya di TPSLN, dapat menyalurkan suaranya kepada pos yang diberikan kepada PPLN di perwakilan negara Indonesia setempat.

Pemberian sanksi dapat dijatuhkan kepada orang yang membantu pemilih penyandang disabilitas apabila dengan sengaja memberitahukan pilihan disabilitas kepada orang lain, dengan ancaman sanksi pidana penjara minimal tiga bulan dan maksimal satu tahun dan denda minimal tiga juta rupiah dan maksimal dua belas juta rupiah.

KPU provinsi Sumatera Barat memberikan akses dan fasilitas dalam pelayanan untuk memudahkan penyandang disabilitas mental dalam memberikan hak pilihnya pada Pemilu Serentak tahun 2019. Berikut adalah tabel pemberian akses yang diberikan okeh KPU provinsi Sumatera Barat.

Tabel 4

Pemberian Aksesbilitas Bagi Disabilitas

\begin{tabular}{|c|c|c|c|}
\hline No & Bentuk Aksesbilitas & Waktu & Keterangan \\
\hline 1 & Sosialisasi & $\begin{array}{l}\text { Sebelum } \\
\text { Pemilu }\end{array}$ & $\begin{array}{c}\text { Semua } \\
\text { Disabilitas }\end{array}$ \\
\hline 2 & Kertas Suara Khusus & Saat Pemilu & Tuna Netra \\
\hline 3 & Alat Bantu & Saat Pemilu & $\begin{array}{c}\text { Semua } \\
\text { Disabilitas }\end{array}$ \\
\hline 4 & Tempat Di Permudah & Saat Pemilu & $\begin{array}{c}\text { Semua } \\
\text { Disabilitas }\end{array}$ \\
\hline 5 & Penerjemah & Saat Pemilu & Tuna Rungu \\
\hline 6 & Pendampingan & Saat Pemilu & Tuna Grahita \\
\hline
\end{tabular}
2019

Sumber: KPU Provinsi Sumatera Barat Tahun

Dari tabel di atas terlihat bahwa pemberian akses dan fasilitas paling banyak dilakukan saat hari H pemilihan. Pada saat pemilu KPU provinsi Sumatera Barat memberikan akses dan fasilitas kepada penyandang disabilitas dalam bentuk kertas suara khusus, alat bantu, tempat, penerjemah dan pendampingan. Sementara pemberian akses dan fasilitas sebelum pemilu dilakukan dalam bentuk sosialisasi. Namun yang belum terlihat adalah pemberian akses dan fasilitas terhadap disabilitas mental . 
Kendala dalam Pemenuhan Hak Pilih Bagi Disabilitas dalam Pemilu Serentak oleh KPU di Sumatera Barat

Pemberian hak politik terhadap masyarakat, terkhusus bagi penyandang disabilitas tentu tidak hanya menjadi tugas dari pemerintah sebagai pembentuk kebijakan. Dibutuhkan berbagai upaya dan mengajak berbagai lembaga baik dari pemerintah ataupun masyarakat untuk ikut serta dan terlibat dalam rangka penghormatan, perlindungan dan pemenuhan hak-hak politik penyandang disabilitas. Sebagai penyelenggara pemilu KPU mempunyai kewajiban dalam memenuhi hak politik semua masyarakat pada penyelenggaraan pemilu terkhususnya terhadap masyarakat penyandang disabilitas.

Upaya-upaya pemenuhan hak politik baik dalam bentuk pelibatan penyandang disabilitas untuk turut serta aktif dalam setiap proses Pemilu, memberikan pemahaman terhadap masyarakat penyandang disabilitas akan kesamaan hak yang dimiliki oleh seluruh masyarakat. Persamaan dan kesetaraan hak tersebut juga menjadi bagian dari hak politik. Meskipun demikian KPU sebagai penyelenggara pemilu tetap mengalami kendala dalam pemenuhan hak pilih bagi penyandang disabilitas dalam pemilu serentak di Sumatera Barat yaitu:

\section{Paradigma Keluarga}

Pandangan atau paradigma keluarga menjadi kendala internal terbesar bagi penyandang disabilitas dalam pemenuhan hak pilih. Masih terdapat keluarga yang tidak memahami hak pilih dan atau masih malu memberikan informasi terhadap petugas sehingga data pemilih disabilitas tidak akurat. Bagi sebagian masyarakat, cacat yang dialami keluarganya diaggap sebagai aib sehingga tidak perlu disebutkan dalam pendataan oleh petugas. Kurangnya pemahaman mengenai hak politik dalam pemilu juga menjadi salah satu hambatan yang ditemukan oleh KPU dalam melakukan upaya-upaya pemenuhan hak politik, juga bagi penyandang disabilitas dalam menyalurkan hak politiknya. Pemahaman mengenai hak politik ini memang tidak dapat serta merta diterima oleh masyarakat secara luas dan menyeluruh.

Berdasarkan hasil Wawancara dengan Icun Sulhadi sebagai Ketua PPDI Kota Padang tanggal 23 Oktober 2020, hal ini muncul karena kendala dari internal yang ditemukan oleh pemilih penyandang disabilitas sehingga tidak menggunakan hak pilihnya:

Merasa tidak nyaman.

Merasa tidak dihargai.

Merasa tidak dibutuhkan hak suaranya.

Kurangnya sosialisasi kepada pemilih penyandang disabilitas.

Kemudian ditambah Kendala dari eksternal yang ditemukan oleh pemilih penyandang disabilitas sehingga tidak menggunakan hak pilihnya:

Pernah terjadi di suatu panti asuhan, ketika hari pemilihan mereka penyandang dissabilitas digiring dan diintervensi dalam menggunakan hak suaranya.

Petugas yang menjadi saksi di TPS harusnya memastikan apakah pemilih penyandang disabilitas ada pendamping atau tidak. Ada intervensi dari pendampingan petugas yang bekerja atau tidak.

Untuk itu, agar semua kendala-kendala yang dihadapi oleh pemilih penyandang disabilitas bisa diatasi dengan beberapa cara yaitu:

Untuk penyelenggara pemilihan agar membangun komunikasi dengan penyandang disabilitas tentang bagaimana teknis pelayanan di lapangan.

Penyelenggara pemilihan hendaknya terbuka dengan ketidakpahaman terhadap pemilih penyandang disabilitas.

Penyelenggara pemilihan harus lebih banyak belajar dari regulasi yang mengatur dan bagaimana dilapangannya.

Untuk saran-saran dari PPDI sebagai OPD belum pernah disampaikan melalui surat ke penyelenggara pemilihan (KPU). Namun pernah disampaikan secara langsung kepada Penyelenggara pemilihan. Kemudian media juga pernah menyuarakan atas kendala-kendala tersebut tapi belum pernah sampai ke tahap jalur litigasi.

Pengawasan dari bawaslu atas pelaksanaan pemenuhan hak pemilih penyandang disabilitas oleh Penyelenggara pemilihan belum maksimal. Evaluasi atas atas pelaksanaan pemenuhan hak pemilih penyandang disabilitas oleh Penyelenggara pemilihan juga masih minim.

Penyandang disabilitas memerlukan tenaga 
pendamping (caregiver) untuk memberikan pelayanan secara terus menerus. Dalam upaya untuk memenuhi kebutuhan pelayanan kepada penyandang disabilitas, sudah seharusnya sebagai pendamping, orang tua mengambil peranan penting dalam memberikan pelayanan dengan tepat, penuh tanggung jawab, dan penuh kasih sayang (Rahman \& Indrayati, 2019).

\section{Paradigma Petugas}

Pandangan atau paradigma petugas menjadi kendala eksternal bagi penyandang disabilitas untuk memenuhi hak pilihnya. Masih terdapat petugas yang kurang memahami serta memiliki ketertabatasan pengetahuan mengenai pentingnya pendataan pemilih penyandang disabilitas. Seringkali petugas pemutakhiran data menganggap keterangan yang diberikan penyandang disabilitas tidak terlalu penting sehingga petugas tidak mendatanya dengan baik. Seringkali petugas pemutakhiran data hanya mengira-ngira mengenai keberadaan penyandang disabilitas tanpa melakukan pencocokan dan penelitian langsung kerumah-rumah masyarakat.

Disamping itu, masih adanya petugas Kelompok Penyelenggara Pemungutan Suara (KPPS), Panitia Pemungutan Suara (PPS), Panitia Pemilihan Kecamatan (PPK) yang tidak menyeluruh dalam mengerti atau memiliki pandangan terhadap disabilitas. Sehingga kondisi petugas-petugas yang seperti itu, mempunyai rasa kepedulian yang kurang, implementasi kerja di lapangan tidak sesuai dengan aturan mengenai teknis pelayanan bagi penyandang disabilitas dalam penyelenggaraan pemilu.

Berdasarkan hasil Wawancara dengan Icun Sulhadi sebagai Ketua PPDI Kota Padang tanggal 23 Oktober 2020, perlakuan khusus yang disiapkan KPU untuk hari $\mathrm{H}$ pemilihan itu tidak ditemukan disetiap TPS. Yang disiapkan secara khusus hanyalah TPS tertentu yang memiliki data pemilih penyandang disabilitas dengan jumlah yang besar dan ditempat-tempat tertentu seperti di Lapas. Sedangkan untuk TP yang hanya memiliki data pemilih penyandang disabilitas hanya beberapa orang, itu tidak ada disiapkan secara khusus. Sehingga seharusnya KPU melakukan beberapa solusi diantaranya:

Setiap TPS disiapkan secara khusus walaupun tidak ada pemilih penyandang disabilitas, namun setidaknya ada pelayanan khusus seperti untuk wanita hamil, pemilih usia lanjut, dll.

Setiap petugas TPS hendaknya diberikan juga pembekaalan khusus, sehingga ketika di hari pemilihan para pemilih disabilitas mendapatkan keterangan yang baik dari petugas sehingga bisa menggunakan hak suaranya sebagaimana mestinya tanpa adanya intervensi dari petugas TPS. Karena tidak semua pemilih penyandang disabilitas yang paham cara penggunaan alat bantu yang disediakan.

Untuk mengatasi kendala paradigma petugas pemilu ini harus dilakukan evaluasi pasca hari pemilihan terkait pemilih penyandang disabilitas oleh KPU itu hanya dilakukan internal KPU. Pada pemilu 2019 ditemukan evaluasi oleh KPU lebih kurang hanya $67 \%$ pemilih penyandaang disabilitas yang menggunakan hak suaranya. Evaluasi yang dilakukan KPU hanya sebatas evaluasi penghitungan tersebut, namun tidak ada kelanjutan evaluasi sebab penyandang disabilitas tersebut tidak menggunakan hak pilihnya.

\section{Minimnya Data Disabilitas}

Melihat dari skala jumlah data untuk Sumatera Barat 1.540 untuk Kota Padang (Data dari KPU). Namun apakah data tersebut valid atau tidak? Kendala di lapangan ketika data KPU ini ingin dikonfirmasi valid atau tidaknya, pihak KPU selalu tidak siap. Sedangkan data anggota yang terdaftar di PPDI ada 300 orang campur Laki-laki dan Perempuan. Namun untuk ketersebaran data untuk penyandang disabilitas itu sendiri lebih dari 3.000 orang dan ini juga belum data penghitungan data yang valid. Sehingga menjadi kendala dari data yang tidak valid. Harapannya data dari KPU tersebut valid karena KPU menggunakan pengisian formulir untuk pemilih disabilitas.

Data awal Daftar Penduduk Potensial Pemilih Pemilu (DP4) yang digunakan penyelenggara pemilu tidak menyebutkan data penyandang disabilitas. Informasi berkaitan dengan hal ini pun tidak terdapat di data pemilu terakhir. Informasi mengenai Penyandang Disabilitas sangat minim sehingga petugas mendapatkan keterbatasan pada pemilih masing-masing kategori disabilitas.

Pada pemilu 2019 terkonfirmasi keterlaksanaan oleh KPU pemenuhan hak-hak disabilitas sesuai dengan amanat UU, pada teorinya sudah tapi belum mencapai pada bagaimana dengan pendekatannya, teknisnya, strategi pengajarannya, bagaimana isunya, keterbukaan keluarga bersangkutan. Berdasarkan data yang didapatkan KPU tersebut harusnya valid karena KPU memiliki cost anggaran yang besar untuk itu, namun apakah setelah melakukan 
pendataan tersebut KPU melakukan pengecekan ulang atau tidak. Keadaan ini menimbulkan dualisme data disabilitas antara KPU dan lembaga lain seperti Kementerian Sosial atau OPD di pusat maupun di daerah. Untuk data pemilih di ibu kota provinsi Sumatera Barat sebgai berikut:

Tabel 5

Data Pemilih Seluruh Disabilitas di Kota Padang

\begin{tabular}{|c|c|c|c|c|c|c|}
\hline \multirow[t]{2}{*}{ No Kecamatan } & \multicolumn{3}{|c|}{$\begin{array}{l}\text { Pemilih } \\
\text { Disabilitas } \\
\text { Yang Terdaftar }\end{array}$} & \multicolumn{3}{|c|}{$\begin{array}{l}\text { Pemilih } \\
\text { Disabilitas } \\
\text { Yang } \\
\text { Menggunakan } \\
\text { Hak Pilih }\end{array}$} \\
\hline & $\begin{array}{l}\text { Laki- } \\
\text { Laki }\end{array}$ & $\begin{array}{l}\text { Perem } \\
\text { puan }\end{array}$ & $\begin{array}{l}\text { Jum } \\
\text { lah }\end{array}$ & $\begin{array}{l}\text { Laki- } \\
\text { Laki }\end{array}$ & $\begin{array}{l}\text { - Perem } \\
\text { puan }\end{array}$ & $\begin{array}{l}\text { Jum } \\
\text { lah }\end{array}$ \\
\hline 1 Padang Selatan & 29 & 35 & 64 & 28 & 35 & 63 \\
\hline 2 Padang Timur & 65 & 68 & 133 & 43 & 47 & 90 \\
\hline 3 Padang Barat & 28 & 35 & 63 & 15 & 24 & 39 \\
\hline 4 Padang Utara & 71 & 79 & 150 & 37 & 38 & 75 \\
\hline $5 \begin{array}{l}\text { Bungus Teluk } \\
\text { Kabung }\end{array}$ & $\mathrm{C}_{23}$ & 11 & 34 & 15 & 10 & 25 \\
\hline $6 \begin{array}{l}\text { Lubuk } \\
\text { Begalung }\end{array}$ & 67 & 81 & 148 & 44 & 57 & 101 \\
\hline 7 Lubuk Kilangan & 35 & 40 & 75 & 20 & 19 & 39 \\
\hline 8 Pauh & 34 & 30 & 64 & 16 & 10 & 26 \\
\hline 9 Kuranji & 62 & 63 & 125 & 56 & 60 & 116 \\
\hline 10 Nanggalo & 61 & 58 & 119 & 28 & 25 & 53 \\
\hline 11 Koto Tangah & 112 & 86 & 198 & 62 & 72 & 134 \\
\hline Total & 587 & 586 & 1173 & 364 & 397 & 761 \\
\hline
\end{tabular}

Sumber: KPU Kota Padang Tahun 2019

Berdasarkan tabel di atas bahwa jumlah seluruh pemilih disabilitas yang terdaftar oleh KPU sebanyak 1173 orang dengan rincian 587 laki-laki dan 586 perempuan. Namun yang penyandang disabilitas yang menggunakan hak pilihnya hanya 761 orang dangan rincian 364 laki -laki dan 397 perempuan. Kondisi ini memperlihatkan bahwa masih banyak penyandang disabilitas yang belum terpenuhi hak pilihnya bahkan jumlahnya bisa bertambah lebih banyak dengan perbedaan data disabilitas saat ini.

\section{KESIMPULAN}

Berdasarkan penjelasan-penjelasan atau uraian -uraian yang telah dikemukakan pada bab terdahulu, maka dapat diambil beberapa kesimpulan sebagai berikut: pemenuhan hak pilih bagi penyandang disabilitas dalam pemilu serentak oleh Komisi Pemilihan Umum (KPU) di Sumatera Barat dilakukan dengan melakukan pendataan, sosialisasi dan memberikan akses. Kendala dalam pemenuhan hak pilih yaitu paradigma keluarga, paradigma petugas dan minimnya data disabilitas.

\section{DAFTAR PUSTAKA}

Anam, K (2011). Pendidikan Pancasila Kewarganegaraan Untuk Mahasiswa. Yogyakarta: Int Media.

Halalia, M. R. (2017). Pemenuhan Hak Politik Penyandang Disabilitas Sesuai Dengan Undang -Undang Nomor 8 Tahun 2016 Tentang Penyandang Disabilitas Oleh Komisi Pemilihan Umum ( KPU ) Kota Yogyakarta. Jurnal Supremasi Hukum, 6(2), 1-24. Retrieved from http://ejournal.uin-suka.ac.id/syariah/

Supremasi/article/view/2016

Huda, N. (2011). Ilmu Negara. Jakarta: Rajawali Pers

Waisnawa, I., \& Dewi, A. (2019). PEMENUHAN HAK PILIH PENYANDANG DISABILITAS SEBAGAI PERWUJUDAN KESETARAAN HAM POLITIK. Kertha Negara : Journal Ilmu Hukum, 7(11), 1-12. Retrieved from https:// ojs.unud.ac.id/index.php/Kerthanegara/article/ view $/ 54800$

Maulana, R., Amarini, I., \& Kartini, I. A. (2020). Pemenuhan Hak Politik Penyandang Disabilitas Mental dalam Pemilihan Umum. Kosmik Hukum, 19(2), 141-151. https:// doi.org/10.30595/kosmikhukum.v19i2.8219

Rahman, M. S., \& Indrayati, R. (2019). Hak Pilih Penyandang Disabilitas dalam Pemilihan Umum di Indonesia. Lentera Hukum, 6(1), 151. https://doi.org/10.19184/ejlh.v6i1.8182

Rahmanto, T. Y. (2019). Hak Pilih Bagi Penyandang Disabilitas Mental Ditinjau dari Perspektif Hak Asasi Manusia. Jurnal HAM, 10(1), 19. https:// doi.org/10.30641/ham.2019.10.19-37

SY, H. C. (2019). Kesetaraan dalam Pemilu. Harian Padang Ekspres. 